\title{
Grundtvigs salmer før Luther
}

\author{
af Jørgen Elbek
}

\section{Et foredrag}

Det er fra mange sider, kirkelige såvel som ukirkelige, blevet sagt at salmerne er kernen i Danmarks digtekunst, og vil man forstå Grundtvigs placering i salmetraditionen kan det være en fordel at se på landets digtning under ét og ikke bare på salmerne.

Det første lyriske indslag der fylder noget i landskabet er folkeviserne - kæmpeviserne som Grundtvig sagde - og dem er der som bekendt selv meget landskab i: "Der dagen han dages og duggen den driver så vide " lyder omkvædet til en vise om hævndrab og bortførelse, og går noget helt galt for folkevisens mennesker går det dog galt inden for naturens rammer: det er "over de sorte heder" at de rider væk, og sørger Ebbe Skammelsen sig ihjel gør han det "som liden fugl på kviste".

$\mathrm{Nu}$ hører folkeviserne jo middelalderen til, men deres sammenhængende, anskuelige naturverden rykker med over grænsen ved reformationen. Man møder den $\mathrm{fx}$ i Hans Christensen Sthens bekendte morgensang "Den mørke nat forgangen er/ og dagen oprinder så vide/ solen hun skinner over mark og kær/ de fugle de sjunge så blide». Sthen er fra slutningen af 1500-tallet, men går vi et stykke op i 1600-tallet, så sker der det forfærdende og uhyggelige at naturharmonien forsvinder totalt, syn og hørelse bliver sat ud af spillet som selvgyldige instanser, og universet bliver spaltet tværs igennem i to: en jord som er her og nu og ingenting er værd, og en himmel som i allerhøjeste grad er sagen, men som er fjern og ikke rigtig til at vide noget om. "Far verden farvel " synger Kingo og henflyr $i$ al ubestemthed til hvilen i Abrahams skød, i forvisning om at himlen skal køre al tingest herom. Denne skarpe opdeling i her og hisset, nuværende timelighed og kommende evighed fortsætter hos Brorson i 1700-tallet, den rokker han ikke ved hvor forskellig han end er 
fra Kingo. Går han blandt blomsterne i enge, gør han det som et barn $\mathrm{i}$ en kort fristund, hans sædvanlige vilkår er vandringen $\mathrm{i}$ syndens lænke og med smertelig erkendelse af at her vil ties, her vil bies.

Heller ikke Grundtvig skaber i første omgang nogen fornyelse, for da han kommer ind i salmernes verden, er det Kingo han knytter an ved. Det sker under hans store krise og religiøse gennembrud i december 1810 da han op mod de tredive, efter nogle års held som forfatter og uheld som elsker, med ét gør den opdagelse at den verden som han så gerne vil frem i og som da også står en mand med hans begavelse åben, den er ikke nogen sand verden, for den har ikke plads til hele ham, kun til hans hoved og ideer. Han selv, hans urolige samvittighed og inderlige angst for at være helt galt afmarcheret, må søge et ganske andet fodfæste som ligger uden for verden med al dens forunderlighed, et fodfæste som ikke kan findes af den der samtidig vil verden som den umiddelbart foreligger. Det kommer nu til at dreje sig om at "elske det der bliver" som der står $i$ en af hans optegnelser fra krisedagene, og alt det der kan ses og høres og foreligger her og nu, om det så er berømmelsen der skyller op om sin mand, det er jo netop kendetegnet ved ikke at være blivende, men underkastet stadig forandring. I den situation fik Kingos salmer noget at sige ham, de viste hen til en fjern himmel hvortil vejen gik gennem korsfæstelse og død. De var ham dybt bekendte fra den tidlige barndom, men senere var der sket det, hos ham som hos alle hans samtidige, at de var blevet fortrængt af de mere moderigtige, til den oplyste tidsånd svarende lovsange fra den evangelisk-kristelige salmebog af 1798 . Nu kom han ikke desto mindre i tanker om de salmer hans gamle værkbrudne barnepige havde siddet og sunget, de talte til ham som dybe sandheder med deres "O Jesus for din pine frels mig fra synderne mine" og indgav ham den kærlighed til det gamle danske sprog som fra nu af til hans dages ende blev så betegnende for ham.

Der var derfor god mening i og personlig baggrund for at Grundtvig nu og altid siden slog til lyd for at de kingoske salmer og de andre fra den danske lutherdoms første 200 år burde genindføres og oplysningstidens trænges ud. De salmeforsøg, han selv lagde ud med var ligeledes $\mathrm{i}$ den gamle syndsbekendende stil. Men ser man så på hvordan han argumenterer for Kingo's 
fortrinsret, er det ikke de skarpe brud, de voldsomme modsætninger, de uoverstigelige kløfter $\mathrm{i}$ hans tilværelsesforståelse det drejer sig om, men derimod en ny form for sammenhæng som arbejder sig frem efter at det begrebsmæssige verdensbillede er gået itu, nemlig fortellingen som jo evner at forbinde stadier der ikke kan findes side om side.

I 1811 offentliggør Grundtvig selv et fortællende digt, nemlig "Dejlig er den himmel blå ", som i virkeligheden er på ca. 50 strofer og rummer hele historien om de hellige tre konger, og $\mathrm{i}$ en fortale til offentliggørelsen taler han de historiske salmers sag. Sådan kalder han dem og det må være sådan noget som Kingos såkaldte Messiade han tænker på - gendigtningen af Kristi lidelseshistorie i 30 salmer hvoraf den sidste er den berømte "Som den gyldne sol frembryder". Grundtvig vil ligefrem selv udgive en samling historisk-kristelige kirkesange hvoraf "en del (som han skriver) skulle være selvgjorte, men den største del borgede af Kingo, Luther og flere af de ældre kristelige digtere med de forandringer, tiden med ret kan fordre". Samlingen blev nu ikke til noget, og sålænge det ikke er gjort klart hvad det er for forandringer som tiden med ret kan fordre, må hele planen vel også kaldes udsigtsløs, et forsøg på at vende tilbage til forladte tider.

Men den historiske opfattelsesmåde, sagaens og fortællingens synsvinkel bliver imidlertid dybt bestemmende for Grundtvigs hele virksomhed de næste mange år, uden at det dog fører frem til den forløsning han higer efter. Han kom da ind på, samtidig med at han oversætter Saxo og Snorre og udsender den ene verdenshistorie efter den anden, at foregribe den ventede forløsning i poesi. De få salmer han skriver i årene frem til 1825 hvor hans næste gennembrud sker drejer sig $\mathrm{i}$ forbavsende mange tilfælde om julen. Det er som om han ser frem til en ny lysets fødsel, som skal finde sted her i Danmark, og et af sine profetiske skrifter kalder han da også "Helligtrekongerlyset ". Over det sætter han som motto følgende ord af de vise mænd fra Østerland: "Vi har set hans stjerne". I denne juledigtning som jo sigter mod et her og nu og ikke et kommende hinsides, en umiddelbar fylde og ikke en salighed til senere indfrielse, $i$ den tvinges han for første gang til at gribe bag om Kingo og Luther til en jævn og folkelig sammenhæng som for ham samtidig bliver et udtryk for 
det højeste høje. Det sker da han i 1820 gendigter "Et barn er født i Bethlehem " som oprindelig er på middelalderlatin, men allerede før reformationen blev oversat til dansk. Salmen er på ti vers, og i de første fem holder Grundtvig sig tæt til sit forlæg som igen følger juleevangeliet - den eneste del af den hellige skrift som folket virkelig har taget til sig, siger Karen Blixen men i anden halvdel skilles vejene: Mens forlægget kører i teologiske begrebsbestemmelser - "I kød og blod er han os lig/ i synden er han os ulig " står der om Jesus - dér udmaler Grundtvig forløsningens herlighed, men således at salighedslivet făr lov at udfolde sig i hjemlige omgivelser, nemlig ude på landet $\mathrm{i}$ Himmelby hvor folk går i kirke ligesom andre steder, men nu sammen med engle og med gud selv som præsten foran altret. Er det nødvendigt at citere? husker ikke alle versene: Guds kære børn vi blev påny,/ skal holde jul i himmelby - På stjernetæpper lyseblå/ skal glade vi til kirke gå - Guds engle dér os lære brat/ at synge som de sang i nat - Da vorde engle vi som de,/ Guds milde ansigt skal vi se. Som et samlet udtryk for sit håb og sin tro kan Grundtvig sætte et motto over salmen som ikke er hentet ud af Biblen eller den kirkelige tradition, men fra et dansk ordsprog: "Det er godt at være barn om julen" - hvad der så at sige erstatter skriftstedet: "Uden at I vender om og bliver som børn kommer I ikke ind i himlenes kongedømme".

Der går nu nogle år efter 1820 , og så kommer Grundtvig ud i det store gennembrud som betegnes af hans lange poetiske tilbageblik Nyårsmorgen som i ramme alvor er blevet kaldt for verdens bedste digt. Blandt det meget der besjæler ham under denne hans genfødsel hvor blodet ruller livsaligt gennem hans årer, hjertet gløder for ånden og ordene strømmer fra ham som aldrig før er også en frisk optagethed af folkeviserne og det for deres hele og fulde menneskeligheds skyld, det samspil og samvirke mellem mandligt og kvindeligt, fædres dåd og moders mål som han nu ser afspejlet i Danmarks historie og Nordens myter. "Man kan umulig kende kæmpeviserne" skriver han op mod 1824 til Ingemann "uden at se at sjælen i dem er helte-kærlighed, som frembringer idel historisk-idylliske optrin, idet en historisk begivenhed står $\mathrm{i}$ forgrunden og indånder det daglige, stille venlige liv en betydning, så det i sammenhæng med heltelivet bliver inderlig poetisk. - Der var intet i Valdemars dage, jeg så gærne 
gad fremstilt, som det indvendige hos Absalons moder og søstre i Fjenneslevlille, dette hus hvor heltehjærtet så åbenbar havde hjemme«. Da han så i årene efter Nyårsmorgen ser det som en nødvendighed at finde kirkeligt udtryk for hvad der rørte sig i ham i de dage da han følte guds kraftige nærværelse, og fik håbet tilbage, er det at han knytter an ved folkeviserne. Det sker i "Den signede dag" som gengiver den såkaldte gamle kristelige dagvise fra senmiddelalderen og som blev skrevet i anledning af tusindårsjubilæet for Ansgars komme til Danmark i 826. I en forbemærkning mere end antyder Grundtvig at Kingo ikke længere er sagen: "Skønt kæmpevisetonen er i salmer blevet os fremmed, må den dog vist findes aldeles passende på takkefesten for tusindåret hvoraf mere end totredjedele henrandt før vi fik danske salmer $\mathrm{i}$ en anden, måske mere kirkelig, men mindre folkelig tone". Denne anklage mod Kingo og kingoister for at være for teologiske $\mathrm{i}$ hovedet, for i klam kirkelighed og stiv ortodoksi at løfte Luthers fane så højt at fødderne slipper den danske jord, den kommer igen i en artikel et par år senere. Her hedder det at man i de gamle protestantiske salmer med grund kunne ønske lidt mere om himmerig og lidt mindre om helvede - hvilket må gå på deres stærke syndsbevidsthed - og at de næsten helt mangler klare udtryk for de klare sandheder om nenneskenes naturlige forhold til gud, hinanden og de timelige kår. Ganske vist er det en fejl at evangelisk-kristelig salmebog lader som om djævelen ikke var til, fortabelsens mulighed ikke eksisterede - det vidste Grundtvig fra sin krise i 1810 at han var og at den gjorde - men på den anden side drejer det sig ikke om at blive ved det gamle i sin halv lutherske, halv pietistiske skikkelse, men om at komme frem til det ny som stræber efter at nå det ældste i sin apostoliske skikkelse. "Den signede dag" er et led i denne stræben. Salmen har folkevisens store idylliske naturbillede med grønne linde, sig bugtende åer og rindende bække, men den er også et juledigt som omhandler lysets fødsel: "Den signede stund, den midnats tid / vor herre han lod sig føde,/ da klared det op i østerlid / til dejligste morgenrøde:/ Da lyset oprandt, som jordens bold / skal lysne udi og gløde".

Der er to sole i digtet, dels den synlige som går over himmelbuen fra morgen til aften, men bagved den stråler åndens sol eller livets lys som oprandt i Danmark ved Ansgars komme og 
som også engang får sin nedgang, sit solbjergslag: "Som aldrig så lang er nogen dag,/ at aften jo er i vente,/ så haver det lys og solbjergslag,/ som gud udi kirken tændte,/ men immer det dages dog på ny,/ hvor hjerterne morgen vente". Det vil sige at salmens naturharmoni som er af middelalderlig rod i virkeligheden står for, afbilder en kreds af mere-end-naturlige, ja mod-naturlige foreteelser - såsom at den himmelske åbenbaring kommer som en funktion af menneskets forventning i kraft af bjergprædikenens logik: søger og I skal finde, banker på og der skal lukkes op. Og ser man nøjere til, viser det sig da også at det går temmelig usædvanligt til rundt om i dagvisens landskab: bækkene snor sig fra engen op under de grønne linde, og ån søger op mod solen som suk der lønligt stiger fra hjertet:

Forgiæves det er, med liden Magt,

At ville mod Bjerg opspringe,

Men Ørnen er snild, han naaer sin Agt,

Naar Veiret ham bær paa Vinge,

Og Lærken hun er en lille Fugl,

Kan lystig i Sky sig svinge!

Med Sus og med Brus den stride Aa

Nedfuser fra Klippe-Tinde,

Ei mæle saa lydt de Bække smaa,

Dog risle de fort og rinde,

Saa frydelig snoe de sig fra Eng,

Op under de grønne Linde!

Saa takke vi Gud, vor Fader god,

Som Lærken i Morgen-Røde,

For Dagen, Han os oprinde lod,

For Livet, Han gav af Døde,

For Alt hvad paa Mark, i tusind Aar,

Der groed til Sjæle-Føde!

Saalænge vi see den gyldne Soel,

Og Skoven er Daners Have,

Da plante vi May i Kirke-Stol,

Og Blomster paa Fædres Grave,

Til glædelig Fest, med Liv og Lyst,

Til mindelig Pindse-Gave! 
Da rinde vel og, som Bakke smaa,

Fra Øine os Taarer milde,

Og Bække i Flok de giør en Aa,

Den higer mod Lysets Kilde,

Den stiger i Løn, som Hjerte-Suk,

Alt aarle, og dog end silde!

Men disse opadgående strømme tegner til gengæld væksten af hjertets skjulte menneske hvis forstand ikke er en løsgjort intellektuel evne, men en følelse der bliver sig selv klar, hvis indsigt kommer fra indre dybder. At det forholder sig sådan, anes allerede i første strofe hvor solen opsvinger fra havet, og sammenhængen gør sig gældende også senere når solstrålerne står i krans om dagens tinde som om en helgens hoved. Livet udgår fra hjertekamret skønt det lyser klarest frem i hovedstaden, har Grundtvig sagt, og det er i tillid til dette skjulte liv, at han ser kirkelivets kommende nedgangstid $\mathrm{i}$ øjnene. Det făr ende $\mathrm{i}$ et andet, "immer det dages dog påny / hvor hjerterne morgen vente". To linjer som Jørgen Bukdahl vist ser som selve kernen i Grundtvigs forfatterskab, og det er faktisk ikke så dårligt set.

Den naturlighed som Grundtvig savner i Kingos salmer er altså ikke en eller anden vild kannibalisme, men den natur som sandheden har frigjort, den forløste skabning for at tale med Paulus, den ikke hellige, men helligede natur, den signede dag.

"Den signede dag " blev som man måske husker anledning til at Grundtvig nedlagde sit præsteembede - han fik forbud mod at anvende den ved gudstjenesten og tog så i 1826 sit gode præstetøj og gik - og da han nogle år senere omkring 1832 trådte $i$ direkte forbindelse med samtiden, var det ud fra andrede forudsætninger. Han havde haft et håb for Danmark, set en stjerne stå over landet, og var kørt fast da han på ligefrem måde havde villet have folket med i sit håb. Men håbet blev til et syn da han kom til England, tidens politisk-økonomiske kraftcentrum, og så hvad en med danskerne beslægtet nation havde drevet det til. Med sig hjem fra England tog han til erstatning for sin forventning en vision af hvad Danmark kunne være, og med dette syn $\mathrm{i}$ sig trådte han atter ind i samtiden, og mens han tidligere havde talt om Danmarks kommende morgenrøde $i$ al ubestemthed 
som var han en profet, så tog han nu fat på de forskellige arbejdsfelter der bød sig til, og hvoraf et var det kirkelige.

Her bliver det nu påsken og ikke længere julen han kredser om som billedet på den ny tids tilblivelse, opstandelsen $\mathrm{i}$ ånden som også tager et legemligt fællesskab med sig. Som en frugt af hans fornyelsesbestræbelser, af hans arbejde på at give sit folks menighed et grundlag for det højere liv den efter hans syn var udset til fremgik i 1837 hans Sangvark til den danske kirke. Det var en kæmpemæssig salmesamling, som i overvejende grad gengiver lovsangen fra de folkeslag der har båret kirken frem gennem historien og det vil i oldtiden sige jøderne, i middelalderen grækerne, de romanske folk og angelsakserne, og under og efter reformationen tyskerne og nu sidst danskerne. Af de mange gendigtninge er det dem fra den førlutherske kirke, der dur bedst, og det hænger sammen med, at her fandt Grundtvig organisk sammenhængende forestillingsbilleder $\mathrm{i}$ stedet for teologiske begreber, abstrakte modsætningspar, her var der simple og tydelige historier, anskuelige og levende skikkelser og landskaber med lys og luft, og de tilbød sig allesammen som udtryk for hvad der egentligst af alt var hans eget. Samtiden dømte at Grundtvig ikke var from nok og ikke ydmyg nok til at skrive egentlige salmer, at hans historisk-poetiske begavelse førte ham ud i den objektive retning til store syner, men at det ikke var ham givet fra disse åndelige syner at tage sig tilbage i det sjælelige livs inderlighed. Men jeg vil sige at Grundtvig gemte på en dybere inderlighed end nogen anden $\mathrm{i}$ tiden, blot skulle den da han var ovre sit livs midte altid vækkes i ydre anledning, men var den der først så vågnede den dybe tone $\mathrm{i}$ hans bryst ligesom højtidssalmen ved kirkeklokkens klang $i$ hans bekendte begravelsessang og midt i sin udadrettede, mod bestemte formål vendte virksomhed tog han sig tilbage og mindedes hvem han egentlig var, nemlig en synder under nåden, den nåde som han har kendt som en forvandling i hjertet, - den mystiske erfaring med Jakob Knudsens udtryk, som hverken Kingo eller Brorson havde oplevet efter deres skrifter at dømme, og som også Kierkegaard og Ingemann stod udenfor.

Den mystiske erfaring kommer til udtryk i en bibelhistorisk sang til skolebrug som handler om kong David og spiller på den 151. Davidssalme, hvoraf de forste $2 / 3$ lyder: "Jeg var lille blandt 
mine brødre, og den yngste i min faders hus. Jeg vogtede min faders får, mine hænder lavede et instrument, og mine fingre spillede på strengeleg. Og hvem fortæller det til min herre? Han er selv herren, selv hører han det. Han udsendte selv sin budbringer, og tog mig fra min fars får og salvede mig med sin salvings olie. Mine brødre var smukke og store, og herren fandt ikke behag i dem..." Den sidste sætning bliver hos Grundtvig til følgende to strofer: "Bæger af guld med den skummende vin/ rakte seeren brat mig i salen,/ salved mit hoved med olie fin/ som en dug over græsset $\mathrm{i}$ dalen. - Mange i salen så skævt til mit held,/ ikke vidste dog nogen min lykke,/ lonlig udsprang der $i$ barmen et vald/ som en kilde i palmernes skygge. "Hvem der kunne sætte disse to linjer på sin gravsten, for det er det skjulte væld $\mathrm{i}$ barmen, strømmen der går gennem hjertet, der er Davids kongestyrke.

Samme mystiske erfaring kommer til udtryk i 84 . Davidssalme, som hos Grundtvig bliver gengivet som "Hyggelig, rolig, Gud, er din bolig ". Her står: "Salig den mand hvis værn er hos dig, herre: i sit hjerte fordeler han opstigninger i grådens dal til stedet han skabte sig ". Og Grundtvig har: "Ja i hans hjerte fra tårernes dal/ trappe du bygger til himmerigs sal" idet Grundtvig klart nok gør vejåbningen i hjertet til guds værk, altså ikke noget man har kontrol over.

Men er selve gennembruddet skjult, omgivet af mystik, et ord som oprindelig betyder lukkethed, så er dets virkning åbenbar og tydelig, synlig for enhver, for den er en forløsning fra det naturlige livsforløb som går gennem forfald henimod død. "Græsset lig er hver en synder/ ender før han ret begynder/ visner i sin vår" står der i Grundtvigs gendigtning af den 92. Davidssalme, men så fortsættes der i næste strofe som er rettet til gud: "Mens i alderdommens dage/ herlig kræfterne tiltage/ hos din gode ven ". Den gode ven ligner Grundtvig selv som allerede var på vej op gennem halvtredserne, og endnu anskueligere er slutstrofen som han føjede til i sine firsere. "Plantede $i$ herrens hus skal de blomstre i vor guds forgårde. Da skal de vinde fylde i rig alderdom " står der hos David, men hos Grundtvig går det på naturligste måde stik mod naturens orden: "Se fra dine drivehuse/ i det fri hvor storme suse/ plantes poder ud!/ Og når de som sne er hvide/ finest frugt om vintertide/ bære de for gud!" Det er 
kun i kraft af en misforståelse at denne strofe er blevet brugt som skolesang, for poderne stammer fra livets skole og hører ikke hjemme på 1-7. klassetrin.

Springer vi nu fra de gammeltestamentelige salmer frem til de middelalderlatinske hymner, så ser vi at Grundtvig slår ned hvor der er størst umiddelbar fylde, men sådan at han ikke bliver stående ved denne. Man kan hæfte sig ved hans to gendigtninge fra den katolske pietisme omkring Bernhard af Clairvaux, en følelsesladet kristendom som gør meget ud af Jesus som person.

Den ene er nadversalmen, skærtorsdagssangen "Vor Herres Jesu mindefest" som bygger på den rimede bøn der kaldes Rosensekvensen. Her tales om synderens inderlige forening med frelseren, men inderligheden er også klarhed: sammen med "hjertenskærlighed/til dig som døden for os led " nævnes "kundskab evig sand/ om livets lys og livets land" og rent ud siges: "En videnskab som kun gud ved/ er livet i din kærlighed " for "kun hvo som elsker kender gud «. For kontrastens skyld kan man sammenligne med en kingosk salme hvori der om nadverforvandlingen står: "Hvordan det sker, det ved jeg ej/ du har ej villet vise mig".

Den anden gendigtning er langfredagssalmen "Hil dig, frelser og forsoner " hvis latinske kilde også ligger bag noget af teksten til Johan Sebastian Bachs Matthæus-passion. I stemning svarer den til Bachs musik: mødet med den korsfæstede vækker en varm anger som optøer "hjertets hårdhed, hjertets kulde», blødgør den forhærdelse fra grunden som livets forløb lægger ned omkring folk. Men opløsningen frigør ikke blot en ny følelsesfylde, men går videre så følelsen parres med indsigt. Denne åndelige, ikke overnaturlige, men mere end naturlige tilværelse er sagen i Grundtvigs vers der lyder: "Du som har dig selv mig givet, / lad i dig mig elske livet,/ så for dig kun hjertet banker/ så kun du i mine tanker/ er den dybe sammenhæng."

Denne tankernes dybe, i hjertet fæstede sammenhæng er ét med livet og virkeligheden. Sådan er det også i de latinske helligåndspåkaldelser hvad nogle spredte citater fra en af Grundtvigs gendigtninge vil godtgøre: "Kærligheds og sandheds ånd!/ Jords og himmels hjertebånd/ knytter du alene.../ Lad det kendes åbenbart:/ lyset dit er mildt og klart,/ det er hjerteglansen,/ du er karligheds forstand..." Modsætningen til helligåndens ild er først 
og fremmest uorden, legemlig hede som stiger til hovedet uden om hjertet ligesom i en rus. "Al uterlighed dig skyr/ spotter med din nåde" står der, og endvidere: "Aldrig tænder bål din ild,/ blusser ej med lue vild/ op til hovedheden ". Modsat hedder det: "Kærlighed til denne jord/ ser du, ak, er såre stor,/ vildt dens lue brænder".

Hvilke virkninger helligånden dermed er at kende på, fremgår af den såkaldte "gyldne sekvens ", som er et af højmiddelalderens berømteste digte og ligesom udtrykker hele dens omfattende kirkelighed. Jeg læser først en ordret oversættelse, ved Johannes Jørgensen, og så Grundtvigs frie, og læg mærke til hvordan man får hymnens tankeudvikling knyttet til to naturgivne helheder, dagens forløb fra morgen til aften og menneskets organisme som har sin midte i hjertet:

Kom, o Helligaand, herned, du, der alting ser og ved, send os Lys og skænk os Fred.

Fader for hver fattig Sjæl, alle gode Gavers Vald, Hjærtets Lys i Livets Kvæld.

Du, hvis Trøst husvaler bedst, Sjælens altid kære Gæst, bring os Fryd og bring os Fest.

Vær en kølig Kildes Vand og et Ly mod Solens Brand og et Smil i Graadens Land.

Lys, som er af Evighed, fyld os med din Salighed, giv os Paradisets Fred.

Uden dig er alt fortabt, thi med Skyld er alting skabt, og vort Paradis er tabt.

Rens os i din Klarheds Tvæt, vand hver gold og gavnløs Plet, foer vi vild, da led os ret. 
Læg vort Hjærtes Ulivssaar, lad den Sjæl, der bladløs staar, bære Blomst i Sol og Vaar.

Alle dem, der paa dig tro, lad dem hos dig fæste Bo $i$ en evig Sabbaths-Ro.

Alle gode Gavers Gud lad os lyde dine Bud, før os frelst af Verden ud.

Amen. Alleluia.

Kom, Gud Hellig-Aand, kom brat, Giennembryd den mørke Nat Med Guds Morgen-Røde! Lad vort Hjertes Lærke-Slag Hilse Herrens klare Dag, Som stod op af Døde!

Sjæle-Sørger allerbedst!

Hjerte-Kamrets ædle Giæst!

Bliv hos os tilstæde Med Guds Fred i Storm og Strid, Evig Trøst i Trængsels Tid!

Sluk vor Sorg med Glæde!

Saligheden, Tvivl til Trods, Giør indlysende for os, Som ved Aand os trøste, Føle dybt, at uden Dig Tomt er alt paa Jorderig, Avner kun at høste.

Styrk og bøi os med din Arm! Giør den kolde Kundskab varm! Dæmp og Luer vilde! Rens os med dit Hjerte-Suk! Kvæg os med din Morgen-Dugg: Dryp fra Livets Kilde! 
Lad for os, som paa Dig troe,

Livets Blomster overgroe

Gravens mørke Tilje;

Og ved Kirke-Gaardens Port

Vift fra os hver Skygge sort

Med din hvide Lilje!

Som man hørte har helligånden på den ene side af sig den afvej som tegnes af den golde intellektualisme, hjernevirksomheden uden rodforbindelse, mens den anden vejgrøft er kødslystens princip som løber ud i tomhed. Grå teori og sansernes rasen går altså hånd $\mathrm{i}$ hånd frem mod menneskets $\mathrm{og}$ menneskehedens ødelæggelse, men i den gyldne midte, hentende kraften hjem fra overdrev og yderligheder, skrider helligånden frem.

Ser vi på oversættelserne fra græsk, springer det først i øjnene, at de næsten allesammen har at gøre med påsken der som nævnt har en særlig vægt for Grundtvig efter Englandsrejserne, dernæst at kvinderne $\mathrm{i}$ Jesu følge får en meget fremtrædende plads. Det vil sige at Grundtvig finder en levende form hvorunder han kan anskue naturen som jeg har talt om i det foregående, både den stivnede og den hærdede natur som er ét med synden, men som angeren løser op for og gør bølgende og strømmende, og den genfødte natur som ånden har gjort levende. Disse to sider af det naturliges væsen træder frem i salmen "Med sin Alabasterkrukke" som går tilbage til græsk. Her optræder naturen under to kvindenavne som står for noget mandligt eller fællesmenneskeligt, nemlig navnene Eva og Maria, Jesu Moder.

Salmen går gennem den græske tekst af nonnen Kassia tilbage til Lukas' beretning om synderinden der salver frelserens fødder mens han er på besøg hos en farisæer. Da farisæeren undrer sig over at han vil befatte sig med en luder, svarer han som bekendt, at den, som făr eftergivet den største gæld også vil være den der elsker eftergiveren højest. Salmen lyder:

Med sin Alabaster-Krukke,

Fuld af Salve dyrebar,

Hun som maatte skamfuld sukke:

Herre, ynkes! Herre, spar!

Kom, med Hjertet sønderknuset, 
Ind i Pharisæer-Huset,

Hvor tilbords den Rene sad!

Synderinden kom med Rødme,

Krukken brat hun sønderbrød,

Salven dyrebar med Sødme

Over Herren hun udgiød,

Lod og sine Taare-Strømme

Herrens Fødder oversvømme.

Tørred med sit Hoved-Haar!

I min Barm, som denne Kvinde, Hjertet føler Banghed stor, Sniger, som den Synderinde, Sig til Dig ved Naadens Bord, Rødmer, blegner, føler Vaanden, Eftergiør det Alt i Aanden,

Sukker: Herre, ynkes, spar!

Som min Gud jeg Dig vil dyrke, Som en Soel for mig oprind!

I min Sjæl er Mulm og Mørke, Midnat uden Maane-Skin, See dog til mig fra det Høie! Speile sig dit Sole-Øie I min stille Taare-Flod!

Himlen sig til Jorden bukked, Dengang Du blev Støvets Søn, Bøi Dig nu til Hjerte-Sukket, Øre dit til Angers Bøn!

Dine Fødder jeg med Glæde Vil i dine Fodspor væde,

Tørre med mit Hoved-Haar!

For din Røst i Kveld fuldbange. Skjulde sig, i Paradis, Eva med de Lokker lange, Jeg dem giver nu til Priis, Mig ei meer jeg vil undskylde, Men med al min Konst forgylde Korset paa din Konge-Vei! 
Mine Synder, dine Domme, Bundløst Dyb at tænke paa, Lad din Naade til dem komme.

Og i Dybde overgaae,

Naar af den jeg er oplivet, Hun, som Meget er tilgivet, Elske vil Dig evig ømt!

Laae Du under Moder-Hjerte, Har Du diet Moder-Bryst, Kiender Du og Kvindens Smerte, Kvinde-Hjertets Liv og Lyst!

O, Marias Søn, du Bolde,

Døm mig ei med Læber kolde!

Skjul mig i din Kiærlighed!

Situationen er en spejlvending af evangeliet hvor Jesus er tavs og kvinden taler. Her taler salmisten til sin gud med en kvinde som medium, og hun den prostituerede som jo tør siges at have levet sig ud som kvinde anråber sin frelser $\mathrm{i}$ en anden, fuldkommen kvindes navn - "O, Marias søn, du bolde/ skjul mig i din kærlighed " - og tager sig selv tilbage i en anger der ikke gælder enkelte handlinger men hele hendes væen - "Kvindens smerte/ kvindehjertets liv og lyst". (Man kan sammenligne med den "hjertets hårdhed, hjertets kulde" som salmisten følte hos sig da han i eget navn mødte sin frelser og forsoner i den tidligere omtalte salme.) Men hinsides angeren, og når den har gjort sit værk, skimtes en anden, mere ophøjet menneskelighed, som anes "hvor til bords den Rene sad" og hvis inderste princip er at den himmelske ild favnes af livgivende vand: "Se dog til mig fra det høje,/ spejle sig dit soleøje/ i min stille tåreflod ". Her har arbejdet med salmerne kaldt "Nyårsmorgen" frem af dets forholdsvise fortrængning hos den senere Grundtvig, for her i "Nyårsmorgen" stod: "At natten er svunden/ med skyggernes hær,/ og solen oprunden/ til heltelig færd/ at glødende voven har favnet dens glans/ at strålende skoven/ den byder sin krans/ at liflig min tunge/ har lyst til at sjunge/, det ingen aftrætte mig skal".

De få oversættelser fra oldengelsk eller angelsaksisk topper i det kendte kvad "I kvæld blev der banket på helvedets port " det skønne kraftige maleri af Kristus i Hades, som Ingemann 
kaldte det. I sin kilde - et langt heltedigt på grundlag af bibelen som tillægges munken Kædmon fra det 7. årh. - fandt Grundtvig en sammenhængende fortælling, en historie med handling $\mathrm{i}$ som han kunne tage fat på. Det har talt til ham at kunne fremstille sin ellers så uanskuelige Kristus som en nordisk høvding, ligesom på et romansk kors, en mandskraftig kæmpe som gør det af med Satan og hans tjenere og udfrier sine folk af fangenskabet dybt under jorden. Men hans egentlige udbytte af sit middelalderlige forlæg er af kvindelig, man fristes til at sige erotisk art, og minder om hans græske salmer, for da Kristus stiger ned i dødsriget som en sol, er det en slags pornomesse han kommer til, et kaos af uoverskuelige lidenskabelige forviklinger som det guddommelige lys ikke gennemtrænger men hægter sig udenpå og lægger sig hen over som løstsiddende kulører: "I helvede skinned guds kærligheds glans,/ guldfarved de djævle kulsorte". Men så føres livskraften tilbage fra sine udartninger og samles i en menneskelig skikkelse, nemlig Evas, og hun anråber Jesus i Jomfru Marias navn og forvandles så fra angrende synderinde til genfødt kvinde med glorie om hovedet: "Da Eva tog ordet, gik frelseren nær,/ og sagde: min søn og min herre!/ jeg ene det voldte, at vi ligger her, / for jeg lod mig dåre, desværre! - Men est du den sæd, mig blev lovet til bod,/ undfanget og født af en kvinde,/ da falder ej moder omsonst dig til fod,/ forlades ej grusom herinde!/ - Fra soløjne milde to tårer nu faldt/ og underfuldt var det at skue:/ med dejlige farver i kronegestalt/ sig danned om Eva en bue! « Man kan måske være i tvivl om fra hvis soløjne det er tårerne falder - jeg tror det er frelserens idet han ynkes over sin stammoder - men afgørende er det, at igen er det ild og vand der mødes hvorefter en ny indsigt opstiger fra hjertet og udstråler fra hovedet.

Vi har fulgt Grundtvig fra 1810'erne og 20'erne da han var julens digter op gennem 30'erne og 40'erne da han blev påskens og $\mathrm{i}$ begge faser forefundet en virksom tilknytning til forreformatorisk digtning, men i 50'erne da han bliver pinsens digter og bl.a. skriver "I al sin glans nu stråler solen ", da slipper han forbindelsen, gendigter $\mathrm{i}$ det hele taget ikke længere, men står omsider på egne ben, om man vil. Denne udvikling kan ses $\mathrm{i}$ lyset af hans egenartede kirkehistoriske syn. Dette sagde ham at syv folkeslag skulle bære kirken frem fra apostlenes dage til 
tidernes ende, og de tre sidste - den tyske, den danske, og muligvis den indiske folkemenighed - skulle svare omvendt til de tre første - den hebraiske, den græske og den latinske - således at dens tyske kirke er inden for protestantismen hvad den latinske var inden for katolicismen og den kommende sidste menighed burde kunne nå op på højde med apostelmenigheden og urkristendommen. $\mathrm{Nu}$ var Grundtvigs problem, da hans personlige modning var tilendebragt omkring midten af 1820 'erne at han var født ind i den lutherske kirke, men først kunne fa hjemme i en dansk menighed, for hvilken han $\mathrm{i}$ al ubestemthed så den græske kirke som forbillede. Hos Luther blev vi kristne levende i ånden, men legemet fulgte ikke med, siger Grundtvig, hvilket vil sige, at fællesskabet, den levende deltagelse $i$ det heles ve og vel, kom til at mangle. Det var under sin forventning om at komme ud af denne enkeltmandskristendom som han havde gennemarbejdet stærkere end nogen anden, at han søgte støtte og styrkelse i de førlutherske salmer. Men da opstandelsen var virkeliggjort, og han så ånden dale over støvet nede på Sydsjælland og hørte himmerigsklokkerne kime før dag i det dunkle en dansk vintermorgen, da forsvandt oldtiden og middelalderen ud af hans virksomhedsfelt for stedse.

Det er fra tid til anden blevet sagt at protestantismen er den eneste religion i verden som ikke ved siden af troen rummer en udøvelse, en fast religiøs praksis som svarer til forestillingsindholdet - skriftemål, godgørenhed og hvad man ellers kan tænke sig. Det var Grundtvigs tanke - kan vi sammenfattende sige - at i Danmark skulle den historiske bevidsthed, samtalen om den fælles fortid og indlemmelsen af den opvoksende slægt i kultursamfundet, være den levende, livsomspændende gudstjeneste uden hvilken protestantismen aldrig kunne blive andet end protest. Således skulle den hellige kirke omsider også blive almindelig - den sande betydning af ordene katolsk, førprotestantisk. 